\title{
From the editors \#30
}

\section{A 10-year perspective on Sexuality, Health and Society - Latin American Journal: updating important issues for the region}

\section{Sérgio Carrara ${ }^{1}$}

> scarrara1@gmail.com

\section{Bruno Zilli²}

> brunozilli@gmail.com

\section{Claudia Mora ${ }^{1}$}

> claudiamoraca@hotmail.com

\section{Silvia Aguião²}

> saguiao@gmail.com

\author{
${ }^{1}$ Universidade do Estado do Rio de Janeiro \\ Departamento de Políticas e Instituições de Saúde \\ Instituto de Medicina Social \\ Rio de Janeiro, Brasil \\ ${ }^{2}$ Centro Latino-Americano em Sexualidade e \\ Direitos Humanos - CLAM \\ Rio de Janeiro, Brasil
}

Copyright @ 2017 Sexualidad, Salud y Sociedad - Revista Latinoamericana. This is an Open Access article distributed under the terms of the Creative Commons Attribution License (http creativecommons.org/licenses/by/4.0/), which permits unrestricted use, distribution, and reproduction in any medium, provided the original work is properly cited. 


\section{From the editors \#30}

\section{A 10-year perspective on Sexuality, Health and Society - Latin American Journal: updating important issues for the region}

It is with great pleasure that the Editorial Team of Sexuality, Health and Society - Latin American Journal publishes it 30th issue. Nearing 10 years of online publication, the journal keeps its regular three issue-per-year periodicity, offering open, free-access content hosted by UERJ, among other indexers. During these years our mission has been the dissemination in the region of scientific content produced in each of its countries, highlighting the perspective of the humanities and social sciences and focusing on topics related to sexuality and gender - which have undeniably social relevance.

Thus, we stress that the publication of the present dossier, complementing the one published in the former issue, expands the debate on one of these topicsrelated to sexually transmitted diseases or infections-which remain a major challenge to public health. If in one hand control of the AIDS epidemic is still incomplete in some countries of the region, on the other hand there is an resurgence of sexuality-related problems which were believed to be surpassed; such as the arising incidence of syphilis in Brazil. Between 2015 and 2016, the number of cases of congenital syphilis increased 4,7\%, targeting 20.474 children. Acquired syphilis cases have increased 26,8\%, targeting 87.593 people (Brasil, 2017).

Presenting in this issue the dossier "HIV/AIDS: sexualities, subjectivities and politics", with a number of important articles, has a special meaning for the Editorial Team. The recent history of sexuality studies in the region is largely intertwined with the very history of the response to the epidemic, which sought-in all its complexity-to join scientific knowledge about the disease and the populations drastically affected by it with respect and promotion of fundamental rights, especially the right to liberty, to dignity and to health. In a sense, it was through this challenge that were renewed a number of other studies on themes equally crucial to the production of differentiated patterns of social vulnerability (Parker \& Aggleton, 2003). Among these are (i) the intersection between gender and sexuality, central to the studies of sexual conventions separating masculinities and femininities; (ii) the intersection between sexuality/gender and generation (or moment of life), focusing on the vulnerability of the "youth" and the "elderly"; and (iii) least but no last, how has been explored the critique of gender and sexuality conventions from scientific fields such as psychiatry, psychology, and psychoanalysis, and its implications in the (re)production of social hierarchies and inequalities. 
The role of academic production in the development of the response to AIDS in Brazil in the initial decades of the epidemic is also important. Such perspective was marked by a critique of the role of science and scientific practice, and the attention to public policies and to ethical principles. The perspective was thus situated on the history of the spaces of academic thinking, including UERJ's Social Medicine Institute, house of the journal. The development of the response to the AIDS epidemic led to the emergence of ethically-based critique of responses inspired by a traditional model of public health. After the advent of bacteriology, such model has postulated that as a medicine able to locate and destroy the microorganism inside the body was sought, a magical bullet of sorts (Brandt, 1987), the public policies should also locate the sick in inside the "social body" and isolate them. In many cases, this led to their social deaths (Daniel, 1989). Parting with this logic, the response to the epidemic in Brazil, for instance, led to the formulation of innovative policies both in the preventive and assistance fields, with results internationally recognized.

The editorial scope of our journal aligns with the critique of universalizing and essencializing approaches, promoting a debate of the assumptions and scientific concepts engaged by researchers. This perspective sustained the idea that sexuality and the causal agents of diseases (such as viruses and bacteria) are political entities, in the sense of them being possible targets of both critique and transformation. To look upon this history and its character goes beyond the recognition of its historical value; it is a necessary task undergoing reinvigoration. The dossier in this issue contributes to this.

Complementing the dossier, the regular articles in this issue are also excellent examples of the thematic reinvigorations, developed in distinct social contexts; including Argentinian, Brazilian, Chilean and Mexican contributions. Estefania Martynowskyj offers an important understanding of how historically tense and complex relations between feminism/women's movement and prostitution are renewed, following the trajectory of the Women of Argentina National Meeting (ENM, in the original), interrogating which femininities they have legitimized for claiming rights. The naturalization of social gender conventions is also the focus of Felipe Magaldi's work on psychiatric institutions and medical-psychological knowledges during the 20th century. Magaldi explores the life of Adelina Gomes, a patient for almost fifty years in a psychiatric hospital in Rio de Janeiro, Brazil. Her artistic work, with more than 17.500 items including paintings and sculptures, is linked to the role of the psychiatrist Nise da Silveira (1905-1999), from the state of Alagoas, in the construction of a humanized model of therapeutic care in dialogue with the Jungian theory.

Two other articles in the regular issue, one from Karla Alejandra Contreras 
Tinoco and Jimena Silva-Segovia, and the other from Daniel Hernández-Rosete Martínez and Rocío Estrada Hipólito, focus on representations and meanings of pleasure/sexual desire and the voluntary interruption of pregnancies of young students from Mexico and Chile, respectively. This issue also includes the article of Suellen Maria Vieira Dantas and Marcia Thereza Couto on the Brazilian National Men's Public Health Policy Program. As in the former two articles, it explores how some gender conventions are interrogated-in this case, the notion that men are invulnerable-through the affirmation of other presuppositions, such as the idea that the medicalization of men's bodies is mainly accomplished through focus on the threats to their sexual potency.

In closing, we invite our readers to look forward for the celebratory issues planned for the ten year anniversary of Sexuality, Health and Society - Latin American Journal. 


\section{References}

BRANDT, Allan M. 1987. No Magic Bullet: A Social History of Venereal Disease in the United States since 1880. Oxford: Oxford University Press.

BRASIL, MS/SVS. 2017. Boletim Epidemiológico. Vol. 48, n. 36.

DANIEL, Herbert. 1989. Vida antes da morte. Rio de Janeiro: ABIA.

PARKER, Richard \& AGGLETON, Peter. 2003. HIV and AIDS-related stigma and discrimination: a conceptual framework and implications for action. Social Science \& Medicine. $\mathrm{N}^{\circ}$ 57, p. 13-24. 